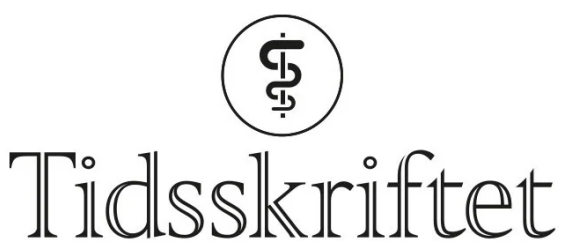

DEN NORSKE LEGEFORENING

\title{
Selektiv mutisme hos barn og unge
}

\author{
KLINISK OVERSIKT
}

\section{HANNE KRISTENSEN}

hannekristens1@gmail.com

Klinisk forskning

Regionsenter for barn og unges psykiske helse (RBUP) Øst og Sør

og

Nic Waals Institutt

Lovisenberg Diakonale Sykehus

Hun har bidratt med å skrive artikkelutkastet og har godkjent den endelige manusversjonen.

Hanne Kristensen er dr.med., pensjonert barnepsykiater, tidligere leder for klinisk forskning ved RBUP og overlege.

Forfatteren har fylt ut ICMJE-skjemaet og oppgir følgende interessekonflikter: Hun mottar royalties som medredaktør av boken Pediatric anxiety disorders, som er referanse nr. 11 i manus. Ingen øvrige royalties.

\section{BEATE $\varnothing R B E C K$}

Klinikk for psykisk helse og avhengighet

Oslo universitetssykehus

Hun har bidratt med kommentarer til og revisjon av førsteutkastet og har godkjent den endelige manusversjonen.

Beate Ørbeck er dr.philos., psykologspesialist og forsker.

Forfatteren har fylt ut ICMJE-skjemaet og oppgir ingen interessekonflikter.

\section{Diagnosen selektiv mutisme beskriver barn som er helt} tause i situasjoner der tale er forventet (som oftest barnehage og skole), mens de snakker hjemme med nære familiemedlemmer. Tidlig intervensjon er vesentlig, men ofte går det lang tid før disse barna blir tilbudt adekvat hjelp.

Selektiv mutisme hos barn og unge kan vare helt til voksen alder og få store konsekvenser sosialt og skolefaglig. En oversiktsartikkel om behandling fra 1998 viste en dominans av kasuistikker med stor variasjon i forklaringsmodeller og intervensjoner (1), mens en nyere oversikt fra 2017 inkluderer kontrollerte behandlingsstudier med en sterkere vekt på atferdsterapeutiske prinsipper (2). Formålet med denne artikkelen er å gi en oversikt over diagnosekriterier, komorbiditet, forekomst/forløp, årsaker, utredning og behandling. Artikkelen baserer seg på forfatternes kliniske erfaring fra feltet samt ikke-systematiske søk i PubMed.

\section{Diagnostikk}


Det er et diagnosekriterium at tausheten er konsistent og av minst en måneds varighet (3). Videre må tilstanden påvirke læring eller sosial funksjon og skal ikke skyldes forbigående taushet ved innlæring av et nytt språk, språkforstyrrelser, autismespekterforstyrrelser, schizofreni eller andre psykoser. I det amerikanske diagnosesystemet (4) er selektiv mutisme kategorisert under angstforstyrrelser, da kliniske studier har vist en assosiasjon med angstlidelser generelt og sosial angstlidelse spesielt (5). Neste utgave av diagnosesystemet International Classification of Diseases (ICD), altså ICD-11, vil følge den amerikanske kategoriseringen.

De diagnostiske kriteriene (3) vektlegger mangel på tale, men tilstanden omfatter også kommunikasjon i videre forstand (bruk av blikk, gester og kroppsspråk). Noen gjør seg godt forstått uten å snakke, mens andre er helt tilstivnet uten gester eller mimikk. Snakkemønsteret varierer også mye. Noen snakker fritt hjemme, mens andre blir tause når fjernere familiemedlemmer besøker hjemmet. På skolen vil noen hviske til enkelte barn i friminuttet, mens andre forblir tause overfor både barn og voksne.

\section{Komorbiditet}

Sosial angstlidelse er hyppigst (70-94\%) (5, 6 ). Depresjon hos barn med selektiv mutisme forekommer sjelden, men prevalensen $ø$ ker noe i ungdomsalderen. Opposisjonell atferdsforstyrrelse og hyperkinetisk forstyrrelse er også mindre vanlig (므).

Utviklingsforsinkelser/forstyrrelser er assosiert med tilstanden. Språkforstyrrelser er hyppigst. Dette er funnet hos ca. 50 \% av barna med selektiv mutisme (7.) mot ca. 10 \% av norske barn generelt (모).

Autismespekterforstyrrelser er et eksklusjonskriterium, men noen barn med autisme kan ha tilstanden. Diagnostisering av disse barna kan være utfordrende, og komorbiditeten har implikasjoner i forhold til tiltak (9.). Selektiv mutisme-karakteristika har også blitt beskrevet ved Cornelia de Langes syndrom (40 \%) og Fragilt X-syndrom (17,8 \%) (10).

\section{Forekomst og forløp}

Prevalenstall varierer fra 0,03\% til 1,9\%(1ㅡ), og de sprikende resultatene skyldes forskjeller i utvalg, alder, informanter og inklusjonskriterier. Tilstanden er rapportert noe hyppigere hos jenter, og symptomdebut er vanligvis i $2-5$ års alder (5). Forløpet ved ubehandlet selektiv mutisme er ukjent, men to retrospektive oppfølgingsstudier med henholdsvis 33 og 45 behandlede pasienter med lengst oppfølgingstid (gjennomsnittlig 12-13 år) fant

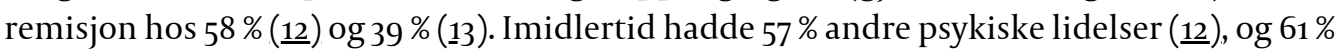
strevde fortsatt med kommunikasjon (13). En nyere retrospektiv studie av 31 pasienter med fire års oppfølgingstid viste at 71 \% av barna fortsatt fylte kriteriene for selektiv mutisme eller sosial angst (14).

\section{Etiologi}

Studier har vist at selektiv mutisme og sosial angst opptrer familiært (7,12, 15). En stor

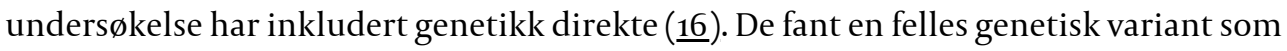
predikerte begge lidelsene. Barn med selektiv mutisme skårer høyt på temperamentstrekk som engstelse og tilbaketrekning overfor nye situasjoner og fremmede mennesker. Disse trekkene har vist seg å predikere angstlidelse generelt og sosial angstlidelse spesielt (17.).

Utviklingsforstyrrelsers betydning for etiologi er uavklart, men en hypotese er at press om å snakke kan føre til taushet hos et barn med språkproblemer, kanskje særlig hvis det også har et tilbaketrukket temperament. Tospråklige barn er overrepresentert (므). En vanlig 
fortolkning er at et forsiktig barn kan reagere med taushet i redsel for å dumme seg ut ved innlæring av et nytt språk og at dette kan utvikle seg videre til selektiv mutisme.

Utløsende faktorer er lite studert. I tidligere litteratur var det søkelys på traumer, men senere empiriske studier har ikke kunnet bekrefte dette (7.). Både i forskning (므) og klinisk praksis beskrives barna som sjenerte fra tidlig alder, og start i barnehage eller skole rapporteres ofte som debut for den selektive tausheten.

Vedlikeholdende faktorer er viktige i forhold til tiltak og må i mangel på relevante studier basere seg på klinisk praksis. Vår erfaring er at en vesentlig faktor er knyttet til redselen for å komme i fokus. Tausheten blir derfor både en løsning og et problem, for dersom barnet begynner å snakke, vil det få oppmerksomhet rettet mot seg. Hvordan omgivelsene forholder seg til taushet, kan også bidra til å opprettholde problemet. Noen reagerer med å stille mange direkte spørsmål, mens andre gir opp samtalen. Ingen av disse løsningene er til hjelp.

\section{Utredning}

Det er som regel barnehage/skolepersonalet eller foreldrene som først reagerer og ønsker hjelp. Den vanligste henvisningsveien til barne- og ungdomspsykiatrisk poliklinikk (BUP) er via fastlege eller pedagogisk-psykologisk tjeneste (PPT). Sistnevnte utreder eventuelle lærevansker og veileder barnehage/skole, mens barne- og ungdomspsykiatrisk poliklinikk har ansvar for diagnostikk og behandling. Minimum av utredning inkluderer diagnostisk intervju for å bekrefte diagnose og avdekke komorbiditet, kartlegging av snakkemønster, utviklingsanamnese og utredning av språk og kognisjon. For nærmere detaljer viser vi til vår nylig oppdaterte veileder (묘).

\section{Behandling}

I kontrollerte behandlingsstudier, hvorav én er norsk, har man funnet at bruk av teknikker fra kognitiv atferdsterapi har gitt en positiv effekt $(9,19)$. Behandlingsprinsippene og de viktigste resultatene fra den norske studien (으) presenteres her kort. For mer detaljer henviser vi til to kapitler om selektiv mutisme $(\underline{11}, \underline{21})$. Mange møter med barn med tilstanden og deres familier ga erfaring med faktorer som hemmet og fremmet kommunikasjon. Det resulterte i en beskrivelse av defokusert kommunikasjon som et grunnleggende prinsipp for å fremme tale i behandling, men også som en hjelp for alle som kommer i kontakt med barn som har tilstanden (ramme 1).

\section{Ramme 1 Defokusert kommunikasjon}

\section{Kontaktregulering}

Reguler blikkontakten ved å se mer på aktiviteten dere holder på med enn direkte på barnet. Gå ikke for tett på og sitt heller ved siden av i stedet for rett overfor.

\section{Form og tema}

Unngå direkte spørsmål. Si heller: «Jeg lurer på om ....» eller «mon tro om ...». Benytt dialog med lite kommunikativt meningsinnhold, som for eksempel en tellelek. Mange barn med selektiv mutisme er livredde for å si noe galt og trenger forsikring om at det er helt greit å komme med feil svar.

\section{Oppretthold «dialogen»}

Unngå å bli taus selv og unngå også å overta samtalen. Legg inn små pauser for at barnet skal kunne respondere. Fortsett å snakke hvis responsen uteblir.

\section{Reguler reaksjonen når barnet begynner å snakke}


Ta det som en selvfølge hvis barnet sier noe. For mye oppmerksomhet er nettopp det barna frykter.

I tillegg til defokusert kommunikasjon består intervensjonen av en trappetrinnsmetode der barnet deltar i et spill som krever enkel verbal kommunikasjon, først med foreldrene og terapeut hjemme og deretter gradvis med terapeut, lærere og andre elever i barnehagen/skolen.

I en pilotstudie med syv førskolebarn snakket seks fritt i alle situasjoner etter gjennomsnittlig 14 uker. Deretter deltok 24 barn i alderen 3-9 år i en randomisert kontrollert studie (behandling versus venteliste). Etter tre måneders behandling fant vi en signifikant økning av tale, mot ingen endring i ventelistegruppen. Ventelistegruppen fikk samme behandling etter tre måneder. Ved fem års oppfølging av deltagerne i disse to studiene fylte $70 \%$ ikke lenger diagnosekriteriene, $17 \%$ var i delvis remisjon mens $13 \%$ fortsatt hadde tilstanden. Yngre alder ved behandling predikerte bedre utfall etter tre

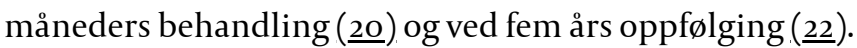

Medikamentell behandling har vært forsøkt, og selektive serotoninreopptakshemmere kan ha en viss effekt (23), men bør først vurderes etter manglende respons på psykologisk behandling.

\section{Tjenestetilbud}

De norske behandlingsstudiene har vist at tidlig intervensjon er viktig. Selv om vi har sett en bedring de senere årene, går det ofte for lang tid før adekvat hjelp blir igangsatt. Kompetansen i hjelpeapparatet varierer, og fremdeles kan familiene oppleve å bli tilbudt behandling uten empirisk grunnlag. Utvikling av gode tjenester for lavprevalente tilstander er en utfordring, og vi ser derfor et behov for en tredjelinjetjeneste der foreldre og behandlere kan henvende seg for veiledning.

Helsesykepleiere og fastleger er sjelden de som først blir oppmerksomme på problemet. Dette kan ha sammenheng med den kortvarige kontakten de har med det enkelte barn og at tausheten blir oppfattet som vanlig sjenanse. Både for å kunne forebygge utvikling av tilstanden hos tilbaketrukne barn og for å komme tidlig i gang med tiltak ved allerede etablert taushet, bør spørsmål om temperament og snakkemønster inkluderes ved både 2og 4-årskontrollen. Ved mistanke om selektiv mutisme bør barnet henvises til barne- og ungdomspsykiatrisk poliklinikk.

Artikkelen er fagfellevurdert.

\section{LITTERATUR}

1. Anstendig K. Selective mutism: A review of the treatment literature by modality from 1980-1996. Psychotherapy (Chic) 1998; 35:381-91. [CrossRef]

2. Zakszeski BN, DuPaul GJ. Reinforce, shape, expose, and fade: a review of treatments for selective mutism (2005-2015). School Ment Health 2016; 9: 1-15. [CrossRef]

3. International Classification of Diseases and related health problems (ICD-10). 10. utg. Geneva: World Health Organization, 1990.

4. Diagnostic and Statistical Manual of Mental Disorders. DSM-5. Washington, DC: American Psychiatric Association, 2013.

5. Driessen J, Blom JD, Muris P et al. Anxiety in children with selective mutism: A meta-analysis. Child Psychiatry Hum Dev 2020; 51:330-41. [PubMed][CrossRef]

6. Gensthaler A, Maichrowitz V, Kaess M et al. Selective mutism: The fraternal twin of childhood social phobia. Psychopathology 2016; 49: 95-107. [PubMed][CrossRef] 
7. Kristensen H. Selective mutism and comorbidity with developmental disorder/delay, anxiety disorder, and elimination disorder. J Am Acad Child Adolesc Psychiatry 200o; 39: 249-56. [PubMed] [CrossRef]

8. Hollund-Møllerhaug L. Forekomst av språkvansker hos norske barn. Tidsskr Nor Psykol foren 2010; 47: 608-10.

9. Muris P, Ollendick TH. Current challenges in the diagnosis and management of selective mutism in children. Psychol Res Behav Manag 2021; 14: 159-67. [PubMed][CrossRef]

10. Moss J, Nelson L, Powis L et al. A comparative study of sociability in Angelman, Cornelia de Lange, Fragile X, Down and Rubinstein Taybi syndromes and autism spectrum disorder. Am J Intellect Dev Disabil 2016; 121: 465-86. [PubMed][CrossRef]

11. Kristensen H, Oerbeck B, Manassis K. Selective mutism. In: Compton SN, Villabø MA, Kristensen H, red. Pediatric anxiety disorders. London: Academic Press, 2019: 225-50.

12. Steinhausen HC, Wachter M, Laimböck K et al. A long-term outcome study of selective mutism in childhood. J Child Psychol Psychiatry 2006; 47: 751-6. [PubMed][CrossRef]

13. Remschmidt H, Poller M, Herpertz-Dahlmann B et al. A follow-up study of 45 patients with elective mutism. Eur Arch Psychiatry Clin Neurosci 2001; 251: 284-96. [PubMed][CrossRef]

14. Kamani Z, Monga S. Understanding the outcome of children who selectively do not speak: A retrospective approach. J Can Acad Child Adolesc Psychiatry 2020; 29: 58-65. [PubMed]

15. Chavira DA, Shipon-Blum E, Hitchcock C et al. Selective mutism and social anxiety disorder: all in the family? J Am Acad Child Adolesc Psychiatry 2007; 46: 1464-72. [PubMed][CrossRef]

16. Stein MB, Yang BZ, Chavira DA et al. A common genetic variant in the neurexin superfamily member CNTNAP2 is associated with increased risk for selective mutism and social anxiety-related traits. Biol Psychiatry 2011; 69: 825-31. [PubMed][CrossRef]

17. Henderson HA, Pine DS, Fox NA. Behavioral inhibition and developmental risk: a dual-processing perspective. Neuropsychopharmacology 2015; 40: 207-24. [PubMed][CrossRef]

18. Lundahl KI, Ørbeck B, Kristensen H. Når taushet ikke er gull. En veileder ved selektiv mutisme. Jaren: PP-tjenestens materiellservice, 2021.

19. Steains SY, Malouff JM, Schutte NS. Efficacy of psychological interventions for selective mutism in children: A meta-analysis of randomized controlled trials. Child Care Health Dev 2021; 47: 771-81. [PubMed][CrossRef]

20. Oerbeck B, Stein MB, Wentzel-Larsen T et al. A randomized controlled trial of a home and schoolbased intervention for selective mutism - defocused communication and behavioural techniques. Child Adolesc Ment Health 2014; 19:192-8. [PubMed][CrossRef]

21. Oerbeck B, Manassis K, Overgaard KR et al. Selective Mutism (norskspråklig utgave). I: Rey JM, Martin A, red. Rey's IACAPAP e-Textbook of Child and Adolescent Mental Health. Geneve: International Association for Child and Adolescent Psychiatry and Allied Professions, 2019.

22. Oerbeck B, Overgaard KR, Stein MB et al. Treatment of selective mutism: a 5-year follow-up study. Eur Child Adolesc Psychiatry 2018; 27: 997-1009. [PubMed][CrossRef]

23. Manassis K, Oerbeck B, Overgaard KR. The use of medication in selective mutism: a systematic review. Eur Child Adolesc Psychiatry 2016; 25: 571-8. [PubMed][CrossRef]

Publisert: 22. november 2021. Tidsskr Nor Legeforen. DOI: 10.4045/tidsskr.21.0354

Mottatt 29.4.2021, første revisjon innsendt 2.9.2021, godkjent 20.9.2021.

Publisert under åpen tilgang CC BY-ND. Lastet ned fra tidsskriftet.no 26. april 2023. 